\title{
Fine Root Mortality Increased by Earthquake Induced Landslides
}

\author{
Yinping Bai1,2, Gang Yang1 \\ ${ }^{1}$ School of Life Science and Engineering, Southwest University of Science and Technology, Mianyang, China \\ ${ }^{2}$ College of Agronomy, Northwest A\&F University, Yangling, China \\ Email: yanggang903@163.com
}

Received 13 July 2016; accepted 12 August 2016; published 15 August 2016

Copyright @ 2016 by authors and Scientific Research Publishing Inc.

This work is licensed under the Creative Commons Attribution International License (CC BY).

http://creativecommons.org/licenses/by/4.0/

(c) (i) Open Access

\begin{abstract}
This study determined the effects of earthquake induced landslide on fine root mortality. It is useful to understand underground soil process after earthquake. We established 9 plots at each of non-moved and landslide site in Cupressus funebris and Cryptomeria fortunei forest stands near the fault belt of the Wenchuan Earthquake. Fine roots were sampled at 0 - 10 and $10-15 \mathrm{~cm}$ soil layer using aluminum cylinders $\left(100 \mathrm{~cm}^{3}\right)$. We found that earthquake induced landslide significantly increased fine root mortality in Cupressus funebris and Cryptomeria fortunei forest stands. Fine root biomass also decreased by landslide at $0-10 \mathrm{~cm}$ soil layer. We observed that the fine root biomass and mortality were various with forest type. There were higher fine root mortality rate $(68.4 \%)$ and lower fine root biomass $\left(0.48 \mathrm{t} / \mathrm{hm}^{2}\right)$ in Cupressus funebris than the Cryptomeria fortunei soils $\left(0.97 \mathrm{t} / \mathrm{hm}^{2}\right.$ and $\left.37.4 \%\right)$.
\end{abstract}

\section{Keywords}

Earthquake, Forest, Landslide, Fine Root, Root Mortality

\section{Introduction}

The Wenchuan Earthquake, with a magnitude of 8.0, was one of the largest earthquakes in the world which not only made people homeless, and caused serious economic losses, but also disturbed ecosystem, soil process and fine root development. Fine root, as an important organ for water and nutrition uptake, is easily damaged by earthquake and disturbs [1]. Intense disturbs would decrease fine root biomass and increase root mortality [2]. However, there has been relatively little information on the earthquake-induced disturbs on fine root biomass and mortality rate.

It was reported that the earthquake moved the forest as much as $60 \mathrm{~m}$ downhill from their original elevations along the slopes [3]. Our previous study discussed the effects of the landslide on soil environment and root pa- 
rameters as well as the causes of the tree death after earthquake. We found earthquake-induced landslides decreased mean tip length/length and mean tip/biomass of fine root [4]. Previous report suggested that fine root was significantly impacted by earthquake [4]-[6]. However, there are no data reported the fine root mortality and the biomass changes under the earthquake. Therefore, the aims of the present study were to 1) evaluate fine root mortality rate in the landslides and 2) to understand whether the fine root mortality disturbed in earthquake various with forest type.

\section{Materials and Methods}

\subsection{Study Site Description}

The study area was located in the northern section of the main seismic fault. It was extended between $\mathrm{N} 31^{\circ} 38^{\prime}-31^{\circ} 49^{\prime}$ and $\mathrm{E} 104^{\circ} 16^{\prime}-104^{\circ} 28^{\prime}$ and elevated between $759 \mathrm{~m}$ and $1397 \mathrm{~m}$. The mean annual precipitation ranged from $1261 \mathrm{~mm}$ to $1399 \mathrm{~mm}$, and the mean annual temperature was from $15.6^{\circ} \mathrm{C}$ to $16.3^{\circ} \mathrm{C}$.

\subsection{Experiment Design}

Cupressus funebris and Cryptomeria fortunei forest were choose to investigate the fine root mortality after earthquake. These two forest stands are main species plantation in this region. All the plantations were with approximately $0.5 \mathrm{~m} \times 0.5 \mathrm{~m}$ density and $23-27$ year old. A total of 11 plots were established at two sites (Shiyan, Shuangdian) near the seismic fault. Each of the plots with $20 \mathrm{~m} \times 20 \mathrm{~m}$ in size. At Shiyan site, 6 plots were located in Cupressus funebris forest, 3 of them were landslide after earthquake and the other 3 were no-landslide. At Shuangdian site, 5 plots were located in Cryptomeria fortunei forest. 2 of them were landslide after earthquake and the other 3 were no-landslide. The landslides were moved $20 \mathrm{~m}$ to $60 \mathrm{~m}$ down from the upper elevations.

\subsection{Root Sampling}

Within each of the plots, 9 points with the distance of 5 meters were determined for the soil collection. At each of the points, three intact soil cores with a $100 \mathrm{~cm}^{3}$ volume $(5 \mathrm{~cm}$ in diameter, and $5 \mathrm{~cm}$ in height) was taken from the surface layer $(0-10 \mathrm{~cm},>10-15 \mathrm{~cm})$, respectively, it contains 198 sample in total. All samples were collection with zip bag and taken to laboratory, and then picking fine root from that. We distinguish live and dead fine root (diameter $<2 \mathrm{~mm}$ ) by root color, elasticity and appearance. Live root elastic, hard, having bright color, died root with darker color and brittle break easily. After picking, live and dead fine root were measured using a digital balance after drying in an oven at $85^{\circ} \mathrm{C}$ for $72 \mathrm{~h}$. Biomass were calculating by the following equation:

Fine root biomass $\left(\mathrm{t} \cdot \mathrm{hm}^{-2}\right)=$ dry weight of soil cylinder $\times 100 /\left[\pi(\mathrm{d} / 2)^{2}\right], \pi$ was pi; $\mathrm{d}$ was the diameter $(\mathrm{cm})$ of soil core [7].

\subsection{Data Analysis}

Analysis of variance (ANOVA) and least significant difference (LSD) were used to assess the species and soil status for fine root biomass. All analyses were performed using SPSS 18.0 (IBM, USA), and graphs were drawn using Sigmaplot 10.0 .

\section{Results and Discussion}

\subsection{Fine Root Biomass and Mortality Rate Changes with Forest Status}

Forests status statistically influenced fine root biomass and mortality at the soil depth of $0-10 \mathrm{~cm}$ and $10-15$ $\mathrm{cm}$ (Table 1). Live fine root biomass was significantly lower in Cupressus funebris $\left(0.48 \mathrm{t} / \mathrm{hm}^{2}\right)$ than the Cryptomeria fortunei soils $\left(0.97 \mathrm{t} / \mathrm{hm}^{2}\right)$ in $0-10 \mathrm{~cm}$ soil layer. However, the live fine root in the soil layer of $10-15$ $\mathrm{cm}$ have no significantly difference between the two forests (Figure 1). Fine root mortality rate in $0-10 \mathrm{~cm}$ and $10-15 \mathrm{~cm}$ soil layer were $68.4 \%$ and $48.4 \%$ in Cupressus funebris. Fine root mortality rate in $0-10 \mathrm{~cm}$ and 10 $15 \mathrm{~cm}$ soil layer were $37.4 \%$ and $57.6 \%$ in Cryptomeria fortunei. Our results suggested that earthquake induced soil physical property changes disturbed soil root growth. Fine root, as a main organ for nutrient and water 


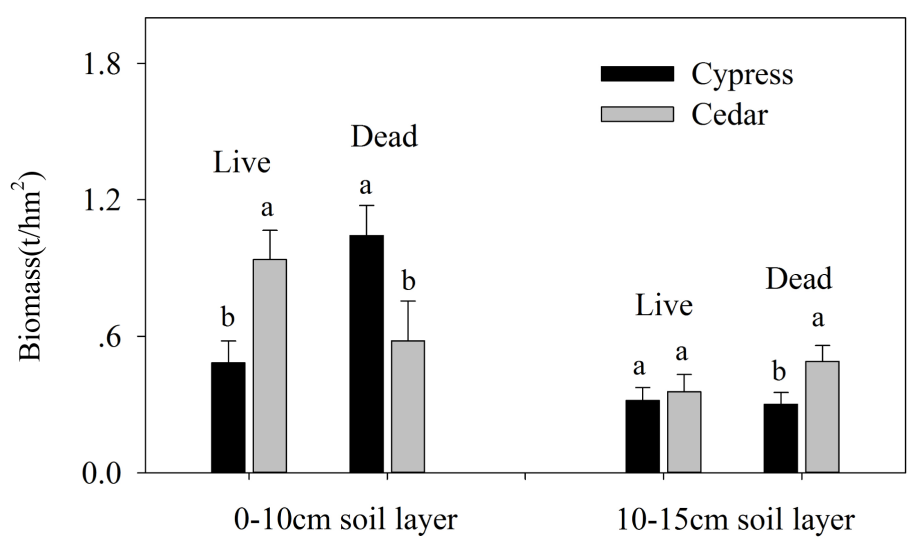

Figure 1. Fine root biomass in different forest species varied with soil depth. Cypress instead of Cupressus funebris, Cedar instead of Cryptomeria fortunei.

Table 1. Analysis of covariance for effects of forest species (Cupressus funebris and Cryptomeria fortunei), soil status (nonmoved and landslide soils) and their interactions on fine root biomass. Bolded number indicates a significant difference $(P<$ 0.05).

\begin{tabular}{rccc}
\hline & Species & Soil status & Species*Soil status \\
\hline Live root $(0-10 \mathrm{~cm})$ & $\mathbf{0 . 0 0 7}$ & $<\mathbf{0 . 0 0 1}$ & $\mathbf{0 . 0 0 8}$ \\
Dead root $(0-10 \mathrm{~cm})$ & $\mathbf{0 . 0 4 0}$ & 0.603 & 0.277 \\
Live root $(10-15 \mathrm{~cm})$ & 0.693 & $\mathbf{0 . 0 0 3}$ & 0.386 \\
Dead root $(10-15 \mathrm{~cm})$ & $\mathbf{0 . 0 3 3}$ & $\mathbf{0 . 0 1 2}$ & $<\mathbf{0 . 0 0 1}$ \\
\hline
\end{tabular}

uptake, were very sensitive to environment disturbs. Large amount of fine root mortality accelerate root turnover in forests. Higher fine root mortality in Cupressus funebris than Cryptomeria fortunei was probably due to smaller specific root area and specific root length in the roots of Cupressus funebris than that of Cryptomeriafortune after the earthquake [6]. Earthquake induced landslide inhibited the elongation of the fine root of $\mathrm{Cu}$ pressus funebris than that of Cryptomeria fortunei.

\subsection{Fine Root Biomass and Mortality Rate Changes with Earthquake Induced Soil Status}

Soil status statistically influenced fine root biomass and mortality at the soil depth of $0-10 \mathrm{~cm}$ and $10-15 \mathrm{~cm}$ (Table 1). Live fine root biomass was significantly lower in landslide plots $\left(0.37 \mathrm{t} / \mathrm{hm}^{2}\right)$ than the no slide plots $\left(1.05 \mathrm{t} / \mathrm{hm}^{2}\right)$ in $0-10 \mathrm{~cm}$ and $10-15 \mathrm{~cm}$ soil layer (Figure 2).

Fine root mortality rate in $0-10 \mathrm{~cm}$ and $10-15 \mathrm{~cm}$ soil layer were $88.4 \%$ and $72.9 \%$ in landslide plots. Fine root mortality rate in $0-10 \mathrm{~cm}$ and $10-15 \mathrm{~cm}$ soil layer were $45.3 \%$ and $36.8 \%$ in no landslide plots. The mechanism of fine root mortality were induced by two main reasons: one was physical injury which induced by landslides; another reason was that earthquake induced landslide makes soil surface compact and dryer. Compact and dryer situation not suit for root development because severe drought may increase the effects of compaction, for example fine roots and tips may shrink due to desiccation [8].

\subsection{The Interactive Effects of Forest and Soil Status on Fine Root Biomass and Mortality}

Forests and soil status statistically influenced fine root biomass and mortality in our study (Table 1). At the plot of Cryptomeria fortunei soils, live fine root biomass were significant lower in slide plots than no slide plot whenever in $0-10 \mathrm{~cm}$ soil layer or in $10-15 \mathrm{~cm}$ soil layer (Figure 3). Dead fine root biomass were higher in slide plots than no slide plot. Fine root mortality rate were higher in landslide plots in both of Cupressus funebris and Cryptomeria fortunei plots. 


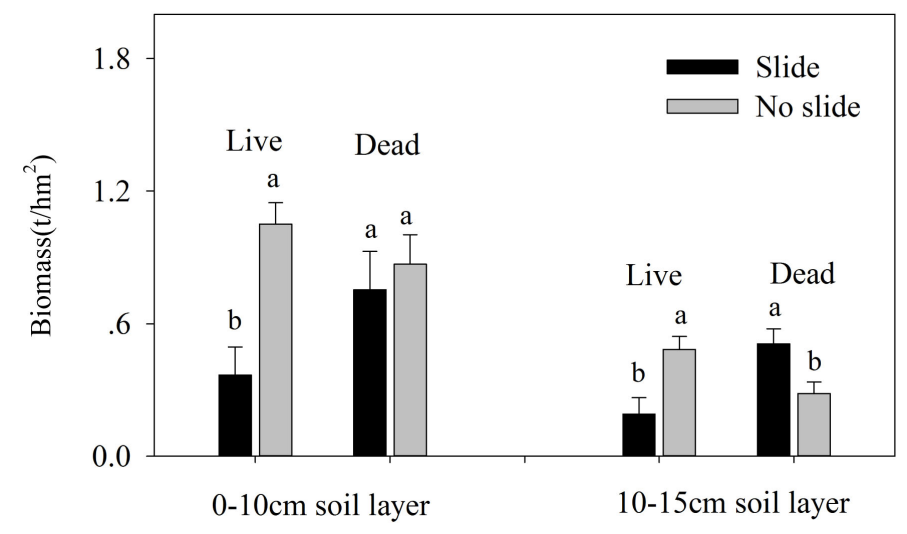

Figure 2. Fine root biomass in different soil status varied with soil depth.

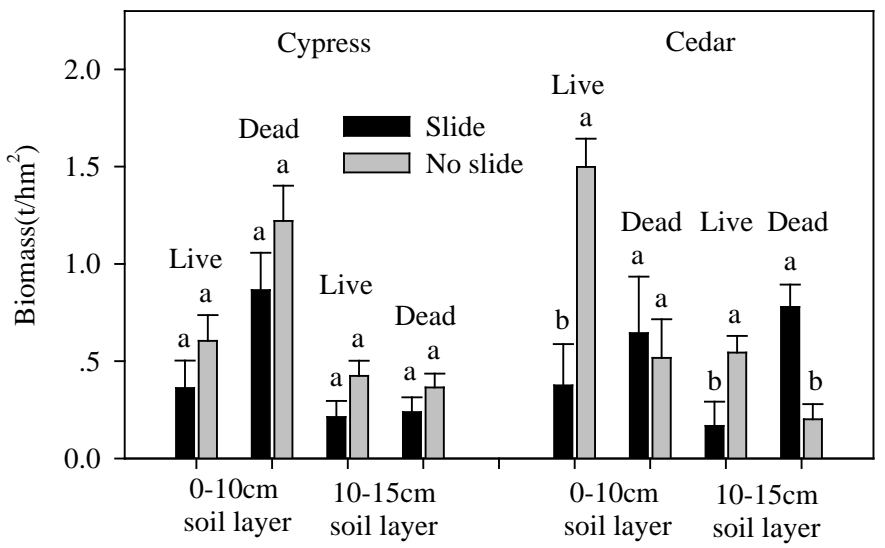

Figure 3. Interactive effects of forest species and soil status on fine root biomass.

\section{Conclusion}

Our data showed that earthquake induced landslides have significantly disturbed fine root biomass and increased fine root mortality in surface layer of forest soil. Fine root mortality rate varied with forest type in our study. Fine root mortality rate in 0 - $10 \mathrm{~cm}$ soil layer was 68.4\% in Cupressus funebris which was higher than that of 37.4\% in Cryptomeria fortunei. It is probably that Cupressus funebris fine root is more sensitive to earthquake induced disturbs.

\section{Acknowledgements}

This work was supported by the Research Funds of Southwest University of Science and Technology (No. 14zx7154). We would like to thank Zhongyong Zhang, Qian He, Yan Su, Bo Chen, Zhihua Li, Rongxi Li, Bo Peng and Gang Xiong for their assistance in the field and laboratory.

\section{References}

[1] Pregitzer, K.S., DeForest, J.L., Burton, A.J., Allen, M.F., Ruess, R.W. and Hendrick, R.L. (2002) Fine Root Architecture of Nine North American Trees. Ecological Monographs, 72, 293-309. http://dx.doi.org/10.1890/0012-9615(2002)072[0293:FRAONN]2.0.CO;2

[2] Joslin, J.D. and Wolfe, M.H. (1999) Disturbances during Minirhizotron Installation Can Affect Root Observation Data. Soil Science Society of America Journal, 63, 218-221. http://dx.doi.org/10.2136/sssaj1999.03615995006300010031x

[3] Schuster, R.L. and Highland, L.M. (2007) Overview of the Effects of Mass Wasting on the Natural Environment. Environmental and Engineering Geoscience, 13, 25-44. http://dx.doi.org/10.2113/gseegeosci.13.1.25

[4] Cheng, S., Yang, G., Yu, H., Li, J. and Zhang, L. (2012) Impacts of Wenchuan Earthquake-Induced Landslides on Soil 
Physical Properties and Tree Growth. Ecological Indicators, 15, 263-270. http://dx.doi.org/10.1016/j.ecolind.2011.09.028

[5] Yang, G., Cheng, S., Yu, H., Zhang, L. and Gao, Y. (2011) Changes in Soil Physical Properties of Forest Floors in the Wenchuan Earthquake-Induced Landslides. (iCBBE) 2011 5th International Conference on Bioinformatics and Biomedical Engineering, Wuhan, 10-12 May 2011, 1-4. http://dx.doi.org/10.1109/icbbe.2011.5781592

[6] Yu, H., Cheng, S., Yang, G., Gao, Y.H., Zhang, Z.Y., Peng, B., et al. (2012) Changes in Cupressus funebris and Cryptomeria fortunei Root Parameters in Landslides Caused by the Wenchuan Earthquake. Advanced Materials Research, 378, 381-384.

[7] Li, X.W., Zhang, J., Chen, W.D., Fan, B. and Dong, H.X. (2005) Study on the Distribution and Growth Characteristics of the Fine Root of Triploidpopulus tomentosa and Root of Lolium multiflorum under Compound Pattern in Both Cultivating Land and Forest. Acta Prataculturae Sinica, 14, 73-78.

[8] Skinner, A.K., Lunt, I.D., Spooner, P. and Mcintyre, S. (2009) The Effect of Soil Compaction on Germination and Early Growth of Eucalyptus albens and an Exotic Annual Grass. Austral Ecology, 36, 698-704. http://dx.doi.org/10.1111/j.1442-9993.2009.01977.x

\section{Submit or recommend next manuscript to SCIRP and we will provide best service for you:}

Accepting pre-submission inquiries through Email, Facebook, LinkedIn, Twitter, etc.

A wide selection of journals (inclusive of 9 subjects, more than 200 journals)

Providing 24-hour high-quality service

User-friendly online submission system

Fair and swift peer-review system

Efficient typesetting and proofreading procedure

Display of the result of downloads and visits, as well as the number of cited articles

Maximum dissemination of your research work

Submit your manuscript at: http://papersubmission.scirp.org/ 